\title{
IMPLEMENTASI TRANSFER PEMBELAJARAN DALAM DIKLAT
}

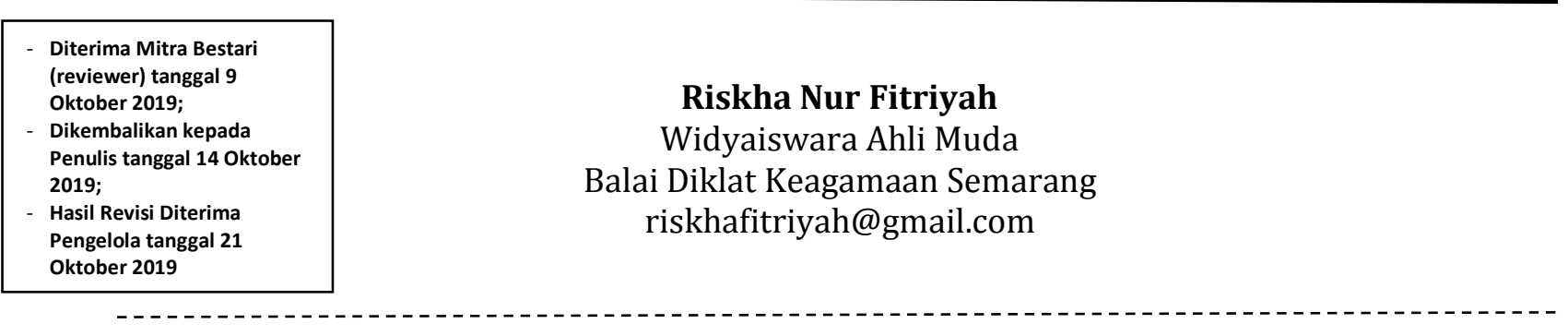

\begin{abstract}
Abstrak
Karya tulis ilmiah ini bertujuan untuk mendeskripsikan sejauh mana alumni diklat mengimplementasikan transfer pembelajaran dan kendala yang dihadapi dalam melakukan transfer pembelajaran. Adapun metode penelitian yang digunakan adalah metode kualitatif yang dilakukan pada kondisi yang alamiah dan memberikan makna dan menguraikan bagaimana orang mengintepretasikan pengalamannya. Sedangkan teknik pengambilan sampel dilakukan secara purposive sampling. Teknik pengumpulan data melalui wawancara dan dokumen. Teknik pemeriksaan keabsahan data yaitu membandingkan hasil wawancara dengan isi dokumen. Dari hasil penelitian didapatkan bahwa transfer pembelajaran telah diimplementasikan oleh alumni diklat kepada teman sejawat (sesama guru) melalui kegiatan diseminasi RTL. Alumni melakukan sosialisasi hasil diklat kepada sesama rekan guru, baik sesama guru Mapel maupun sesama guru di lingkungan madrasah (MGMP tingkat madrasah), KKG/MGMP tingkat kecamatan sampai tingkat Kabupaten/Kota dengan jumlah peserta 5 sampai 50 guru. Beberapa kendala yang dihadapi alumni diklat dalam melakukan transfer pembelajaran melalui kegiatan diseminasi antara lain : adalah motivasi diri sendiri, dukungan dan komitment atasan (Kepala Madrasah), iklim dan lingkungan di madrasah serta perencanaan waktu kegiatan diseminasi yang kurang sesuai. Adapun saran yang dapat disampaikan yaitu agar program pemberdayaan alumni mendapat perhatian dan dapat menjadi salah satu program prioritas, serta menjadi salah satu bahan untuk melakukan evaluasi evaluasi pasca diklat.
\end{abstract}

Kata kunci : transfer pembelajaran, implementasi RTL, diseminasi

\section{A. PENDAHUluan}

\section{Latar Belakang}

Pendidikan dan pelatihan (diklat) merupakan suatu proses pembelajaran dalam organisasi yang mengarah pada perubahan sikap dan perilaku pegawai dalam memenuhi harapan kualifikasi kerja dan tuntutan perkembangan organisasi baik internal maupun eksternal. Diklat secara teori merupakan upaya untuk mengembangkan sumber daya aparatur, terutama untuk peningkatan profesionalime yang

$$
\begin{aligned}
& \text { berkaitan dengan, keterampilan } \\
& \text { administrasi dan keterampilan } \\
& \text { manajemen (kepemimpinan). } \\
& \text { Sedarmayanti dalam Hanum (2018) } \\
& \text { berpendapat bahwa untuk }
\end{aligned}
$$

meningkatkan kualitas kemampuan yang menyangkut kemampuan kerja, berpikir dan keterampilan maka pendidikan dan pelatihan yang paling penting diperlukan. Devi \& Shaik dalam Julifan (2015) menyebutkan bahwa fungsi dari pelatihan memungkinkan sumber daya manusia untuk memunculkan potensi 
mereka. Sebuah program pelatihan yang mendalam berperan sebagai alat untuk meningkatkan keterampilan pegawai dan memungkinkan mereka untuk melakukan pekerjaannya dengan lebih baik. Pelatihan dan pengembangan sangat penting bagi pegawai, karyawan, organisasi, dan efektivitas organisasi.

Salah satu sasaran pembangunan nasional di bidang pendidikan adalah peningkatan mutu pendidikan, dan faktor yang paling mendasar dan sangat menentukan mutu pendidikan adalah guru, sebab peran guru sangat signifikan dalam proses pembelajaran. Pemerintah telah melakukan penyempurnaan sistem pendidikan yakni pembinaan dan peningkatan kompetensi guru melalui diklat (Julifan, 2015). Berkenaan dengan guru madrasah, baik guru MI, MTs dan MA Pemerintah melalui Kementerian Agama, dalam hal ini Badan Litbang dan Diklat telah menyelenggarakan berbagai jenis diklat dan melakukan penyempurnaan kurikulum diklat sesuai dengan kebutuhan para guru. Balai Diklat Keagamaan Semarang, merupakan unit pelaksana teknis yang memiliki tanggungjawab untuk meningkatkan kompetensi aparatur Kementerian Agama di Provinsi Jawa Tengah dan DIY. Dalam perjalanan kiprahnya telah banyak melahirkan alumni diklat. Kritikan yang masih sering didapatkan karena belum sesuai antara kompetensi yang menjadi tujuan diklat dengan kebutuhan stakeholders.

Keberhasilan penyelenggaraan diklat ditentukan oleh banyak fakor, diantaranya penentuan tujuan, pengembangan kurikulum, penyusunan program, penetapan peserta dan wisyaiswara, penyelenggaraan administrasi dan keuangan, proses pembelajaran serta lingkungan. Oleh karena itu, lembaga kediklatan harus mampu menunjukkan profesionalitasnya sebagai penyelenggara diklat, serta mampu menciptakan tenaga-tenaga guru yang handal dan professional (Hanum, 2018). Namun dalam kenyataannya, hasil diklat tidak cukup signifikan dengan peningkatan kinerjanya. Bahkan, pelatihan yang diberikan oleh lembagalembaga penyelenggara diklat yang berkualitas dan terkenal sering hanya memberikan "refreshment" bagi para peserta diklat (Haryanto, 2011). Wibowo (2013) dalam penelitiannya dengan judul "Kinerja Guru Agama Madrasah Aliyah Pasca Diklat Fungsional Di Propinsi Nusa Tenggara Barat" menyatakan bahwa guru agama tampak belum melakukan kegiatan membagi pengalaman atau menularkan ilmu yang diperolehnya melalui diklat yang diikutnya kepada guru lain. Terkait dengan kompetensi kepribadian guru, dari hasil penelitian menunjukan bahwa 
aspek bertindak sesuai dengan norma hukum memperoleh rerata 82,72. Aspek menunjukan pribadi yang dewasa dan tauladan memperoleh rerata 74,54 . Etos kerja dan tanggung jawab memperoleh rerata 65,90. Jika ketiganya di rerata maka kompetensi kepribadian ini memperoleh nilai 74, 386. Secara idealitas berdasarkan Permenengpan No 16 tahun 2009 nilai 74, 386 ini masih belum memenuhi kriteria standard Permenegpan mengenai standard kinerja guru yang menetapkan nilai 75 . Selama ini, setelah guru selesai mengikuti diklat tidak membuat laporan tertulis dan tidak melakukan sosialisasi terhadap ilmu yang diperolehnya.

Untuk mengatasi hal tersebut, Badan Litbang dan Diklat Kementerian Agama sebagai unit Eselon I, dalam hal ini Pusdiklat Tenaga Teknis Pendidikan dan Keagamaan telah mengeluarkan Surat Edaran Nomor: 1186/P.V.3/KP.02.2/05/2018 tanggal 17 Mei 2018 tentang pelaksanaan Rencana Tindak Lanjut (RTL) bagi seluruh UPT di daerah (Balai Diklat Keagamaan). Balai Diklat Keagamaan sebagai UPT di daerah telah mewajibkan para peserta diklat untuk membuat Rencana Tindak Lanjut (RTL) dan mendiseminasikannya sebagai upaya transfer pembelajaran. Setelah para alumni diklat mendiseminasikan hasil diklat, diwajibkan menyusun laporan implementasi RTL.

Diklat dirancang untuk memfasilitasi proses pembelajaran bagi para peserta agar mereka dapat mengembangkan pengetahuan, keterampilan dan sikap yang dibutuhkan di tempat kerja. Efektifitas penyelenggaraan diklat akan menjadi masukan (feedback) yang sangat penting dalam memperbaiki kualitas diklat dan menjaga keberlanjutan instansi/lembaga penyelenggara diklat. Learning transfer (transfer pembelajaran) penting dilaksanakan sebagai usaha pengembangan pegawai terutama untuk mencapai efektivitas dan efisiensi pelaksanaan diklat yang diterapkan di tempat kerja sehingga membawa hasil yang optimal bagi organisasi (Grove and Ostroff dalam Hastari (2013). Berdasarkan deskripsi di atas, tulisan ini mengkaji tentang "implementasi transfer pembelajaran alumni diklat".

\section{Rumusan Masalah dan Tujuan}

Adapun pertanyaan penelitiannya adalah

1. Sejauhmana alumni diklat mengimplementasikan transfer pembelajaran?

2. Apa saja kendala yang dihadapi dalam melakukan transfer pembelajaran? 
Tulisan ini bertujuan untuk :

1. Mengetahui sejauhmana alumni diklat mengimplementasikan transfer pembelajaran?

2. Mengidentifikasi kendala yang dihadapi dalam melakukan transfer pembelajaran?

\section{B. KAJIAN TEORI}

\section{Teori Transfer dalam Diklat}

Pada tahap transfer dalam pelatihan, teori yang digunakan adalah Teori Elemen Identik (Identical Element Theory) dan Teori Transfer Kognitif (Kognitif Transfer Theory). Teori elemen identik merupakan transfer dari satu situasi ke situasi yang lain baru terjadi jika antara kedua situasi terdapat unsur unsur yang identik. Besar kecilnya nilai transfer tergantung pada banyak sedikitnya unsur yang identik dalam situasi yang dipelajari (Soekamto, 1997). Teori elemen identik mengemukakan bahwa transfer dalam pelatihan terjadi ketika apa yang disampaikan instruktur, baik materi maupun praktek pemecahan masalah dalam suatu pelatihan identik atau mirip dengan pelaksanaan dalam tugas sehari - hari di tempat kerja. Sehingga transfer akan berjalan maksimal apabila tugas, bahan, peralatan, dan karakteristik lingkungan belajar dalam suatu pelatihan mirip dengan yang ditemukan di lingkungan kerja. Salah satu metode dalam pelatihan yang sesuai dengan konsep teori elemen identik adalah simulasi. Peserta pelatihan yang terlibat dalam simulasi, akan dievaluasi oleh instruktur. Kemudian instruktur memberikan umpan balik kepada peserta secara tertulis setelah mereka menyelesaikan simulasi atau instruktur dapat memperbaiki kesalahan yang terjadi (Noe, 2010).

Menurut teori transfer kognitif, transfer pelatihan tergantung pada kemampuan peserta dalam menerima materi selama pelatihan. Teori ini menunjukkan bahwa kemungkinan transfer meningkat dengan memberikan pelatihan yang bermakna. Selain itu pemilihan instruktur yang profesional juga mendukunga dalam transfer pelatihan. Pengaruh teori transfer kognitif dalam pelatihan dengan desain yang dapat mendorong peserta pelatihan. Banyak program pelatihan dengan peserta yang dapat mengidentifikasi masalah pekerjaan atau situasi yang kemudian mendiskusikan dalam pelatihan. Metode yang berdasarkan atas pemecahan masalah dapat mempermudah peserta dalam mengingat isi pelatihan dan menerapkannya pada pekerjaan ketika mereka menghadapi masalah di lingkungan kerja (Noe, 2010).

\section{Hasil Diklat}

Istilah pelatihan sering didefinisikan sebagai sebuah pengalaman pembelajaran yang terencana yang dirancang untuk 
menghasilkan perubahan permanen dalam pengetahuan, sikap atau ketrampilan. Pelatihan juga dapat didefinisikan sebagai proses sistematik untuk memiliki sikap, konsep, pengetahuan, peran atau keterampilan yang berakibat pada perbaikan kinerja di tempat kerja. Menurut definisi ini tujuan pelatihan tidak lain adalah untuk membantu orang-orang mengembangkan keterampilan dan kemampuan yang, bila diaplikasikan di tempat kerja, akan memperbaiki kinerja jabatan mereka di jabatan mereka sekarang. Definisi ini mensyaratkan dua komponen penting dalam pelatihan, yakni pelatihan dan aplikasi bagi pelatihan (Goldstein dalam Edward dan Sumarni, 2013). Diklat yang dilaksanakan harus berkaitan dengan pekerjaan yang akan dihadapi dengan pemberian keterampilan yang tepat, sehingga sesuai dengan kebutuhan peserta. Program diklat perlu dibuat berdasarkan analisis kebutuhan pekerjaan yang akan dihadapi peserta sehingga kualitas hasil diklat benar - benar dapat diimplementasikan oleh peserta (Hatton dalam Julifan, 2015).

Produk suatu proses pendidikan dan pelatihan adalah berupa output atau alumni peserta pelatihan, sedangkan manfaat produk lebih lanjut adalah berupa outcome, yaitu bagaimana pengaruh pelatihan terhadap kinerja nyata seorang peserta diklat. Sejatinya harapan dan tujuan dari pelaksanaan diklat adalah terpenuhinya kompetensi kognitif, sikap maupun keterampilan yang mendorong profesionalitas kerja. Diklat bagi pegawai merupakan proses pembelajaran yang mengarah pada perubahan kemampuan, sikap, dan perilaku sesuai tujuan dari jenis-jenis diklat. Pembelajaran itu sendiri akan diadopsi dari pengalaman yang dialami pegawai selama mengikuti program diklat baik secara teoretis maupun secara praktis. Hasil yang dicapai peserta diklat diharapkan menjadi bekal yang menunjang profesionalitas kerja setelah kembali ke tempat tugasnya masing-masing. Bagi para guru, pengetahuan yang diperoleh selama mengikuti diklat dituntut mampu diimplementasikannya dalam proses belajar mengajar di kelas, ada sesuatu yang baru didapatkan tersebut menjadi pemicu inovasi pembelajaran dari waktu ke waktu dan pada akhirnya dapat mencapai tujuan pendidikan yang membutuhkan energi besar (Asmu'i dalam Asroi 2013).

Hasil dari diklat dapat berupa pengetahuan (knowledge), pengalaman dan ketrampilan (skill). Wibowo (2013) menjelaskan bahwa pengimplementasian hasil kediklatan guru meliputi hal - hal adalah kualitas sumber daya manusia, kondisi sosial ekonomi, fasilitas, sosiokultural, dan struktural. Sumber daya manusia yang dapat 
mengimplementasikan hasil diklat harus memiliki kualifikasi seperti motivasi tinggi, kompetensi dalam bidangnya, dan kreativitas yang tinggi. Fasilitas yang tersedia di madrasah memberikan peluang bagi guru untuk memilih secara tepat cara apa yang sesuai dengan tujuan pembelajaran dapat berlangsung menyenangkan dan menarik. Hambatan yang sangat dirasakan oleh para guru adalah tidak adanya monitoring dan evaluasi dalam melaksanakan hasil diklat. Dengan kata lain diklat yang diberikan belum bersifat operasional, tetapi masih pada tataran teoretis atau konsep.

\section{Transfer Pembelajaran}

Pembelajaran adalah aktivitas dari keseluruhan yang memiliki pengetahuan, keahlian dan komponen sikap peserta diperlukan untuk menghasilkan perubahan dalam cara bekerja. Suatu pembelajaran terjadi ketika pengetahuan maupun ketrampilan yang baru atau berubah telah diperoleh/dikembangkan dapat ditempatkan pada pekerjaan yang kemuadian digunakan secara tetap atau paling tidak digunakan dalam beberapa waktu tertentu (Hastari, 2013). Transfer pembelajaran adalah suatu format aplikasi dan penyamarataan ke situasi di luar pelatihan. Transfer pembelajaran dipertimbangkan sebagai penyamarataan dari ketrampilan yang diperoleh sepanjang tahap pelatihan pada lingkungan pekerjaan dan pemeliharaan ketrampilan yang diperoleh dari waktu ke waktu. Kemampuan transfer pembelajaran merupakan hasil yang diinginkan oleh pelatih (Tasse et.al, 2005). Dalam transfer pembelajaran, beberapa faktor yang mempengaruhi antara lain : sistem, kebijakan, program tindak lanjut, dukungan dari manajemen untuk secara efektif menggunakan skill, knowledge dan ability yang baru diperoleh dari pelatihan ke tempat kerja, sehingga apa yang telah diperoleh dan dipelajari dipelatihan dapat diujicobakan dalam pekerjaannya.

Transfer pembelajaran muncul ketika individu menggunakan pengetahuan yang terlebih dahulu diperoleh dari situasi atau peristiwa pembelajaran dan mampu menerapkannya pada situasi baru. Atau kapan saja ketika pengetahuan dan ketrampilan yang dipelajari dapat mempengaruhi cara yang ditempuh dimana pengetahuan dan ketrampilan baru dipelajari dan dilakukan. Learning transfer didefinisikan sebagai kemampuan untuk memperluas apa yang telah dipelajari pada satu konteks ke konteks yang baru. Transfer pengetahuan, kemampuan dan ketrampilan dapat berlangsung kapan saja, dan berpengaruh oleh derajat tingkatan dimana orang belajar dengan pemahaman. Faktor yang mempengaruhi suksesnya transfer adalah derajat tingkat penguasaan yang cukup 
dari awal pembelajaran sehingga transfer bisa diharapkan (Hastari, 2013).

\section{Rencana Tindak Lanjut}

Salah satu kebijakan yang dikeluarkan oleh Pusdiklat Tenaga Teknis Pendidikan dan Keagamaan untuk menjaga agar penyelenggaraan diklat dapat optimal dan benar-benar dapat dirasakan hasilnya oleh stakeholders, maka diedarkanlah Surat Nomor: 1186/P.V.3/KP.02.2/05/2018 tanggal 17

Mei 2018 tentang pelaksanaan Rencana Tindak Lanjut (RTL). Isi dari surat tersebut, mensyaratkan bahwa setiap peserta diklat wajib membuat Rencana Tindak Lanjut (RTL) dan setiap alumni diklat yang sudah kembali ke madrasah harus melakukan diseminasi (menularkan pengetahuan dan ketrampilan yang diperoleh) kepada teman sejawat sesuai RTL yang telah dibuat dan membuat Laporan Implementasi RTL.

Diseminasi bertujuan untuk menyediakan/menyajikan hasil dari suatu kegiatan agar tersedia untuk orang lain yang tidak secara langsung ikut terlibat atau menjadi sasaran dalam kegiatan tersebut. Diseminasi merupakan suatu kegiatan penyebarluasan segala bentuk informasi atau hasil dari suatu kegiatan kepada orang lain yang tidak mengikuti kegiatan tersebut secara langsung. Diseminasi hasil diklat juga dapat diartikan sebagai segala bentuk kegiatan penyebarluasan informasi atau hasil yang diperoleh selama mengikuti diklat kepada orang lain yang tidak secara langsung mengikuti diklat. Dengan demikian diseminasi diklat yang disusun dalam program tindak lanjut diklat bertujuan untuk menyampaikan/ menginformasikan hasil diklat (Wijaya, 2013). Transfer pembelajaran digunakan untuk melihat sejauh mana pengetahuan yang dipelajari memiliki kegunaan atau ditindaklanjuti di tempat kerja untuk menemukan sejauh mana pengetahuan itu berguna. Pengetahuan setiap individu untuk mentransfer pengetahuan dan ketrampilan secara efektif dan efisien yang kemudian menerapkannya ke situasi serupa akan menentukan tingkat dari transfer atau perpindahan.

\section{METODE PENELITIAN}

Pendekatan penelitian yang digunakan adalah deskriptif kualitatif, yakni penelitian yang bersifat alami untuk mengeksplorasi data dari sumber-sumber tertentu. Sugiyono (2013) menjelaskan bahwa kualitatif sering disebut metode naturalistik karena penelitiannya dilakukan pada kondisi yang alamiah (natural setting), seluruh tujuan penelitian kualitatif adalah untuk mencapai pemahaman bagaimana orang-orang merasakan dalam proses kehidupannya, memberikan makna dan menguraikan bagaimana orang mengintepretasikan 
pengalamannya. Peneliti menggunakan metode penelitian kualitatif karena peneliti ingin memahami sejauhmana alumni diklat menginterpretasikan pengalamannya melakukan diseminasi RTL sampai menyusun laporan implementasi RTL. Sedangkan teknik pengambilan sampel dilakukan secara purposive sampling. Teknik pengumpulan data melalui wawancara dan dokumen. Teknis analisis data digunakan dengan reduksi data, penyajian data dan penarikan kesimpulan. Teknik pemeriksaan keabsahan data yaitu membandingkan hasil wawancara dengan isi dokumen berupa laporan hasil implementasi RTL.

Dalam mengukur transfer of learning (transfer pembelajaran), kriteria yang paling umum di pakai adalah membandingkan kinerja sebelum dan setelah mengikuti diklat. Untuk membandingkan kinerja tersebut, indikator yang dipakai adalah relevansi pelatihan dengan pekerjaan, pengaruh pelatihan dengan pekerjaan, aplikasi materi pelatihan kedalam pekerjaan (Helfenstein, Kirwan, Pucel and Cerrito dalam Pertissa, 2015).

\section{HASIL PENELITIAN DAN PEMBAHASAN}

Para pegawai yang selesai mengikuti sebuah program diklat dan kembali ke tempat tugas, diharapkan mampu untuk mentransferkan skill dan pengetahuan yang mereka dapatkan dalam program diklat yang diikuti ke pekerjaan mereka sehari-hari. Dampak dari penerapan skill dan ilmu pengetahuan tersebut dapat merubah perilaku yang dapat mendorong efektifitas dan efisiensi dalam bekerja. Pelaksanaan diklat pada sebuah instansi diharapkan mampu menunjang kesuksesan untuk mencapai tujuan yang hendak dicapai, karena pada dasarnya diklat merupakan sebuah proses perubahan sikap maupun perilaku. Sebuah diklat yang efektif adalah selalu mengandung pengalaman belajar dan didesain serta dirancang berdasarkan kebutuhan peserta diklat. Dengan peningkatan kualitas alumni diklat, maka akan memperkecil tingkat kesenjangan antara penguasaan pengetahuan yang dimiliki dengan ketrampilan yang dibutuhkan oleh instansi. Dengan demikian akan terjadi efisiensi dan efektivitas kerja dalam mencapai tujuan yang telah ditetapkan (Hastari, 2013).

Berikut hasil wawancara dengan alumni diklat, Pak Fauzan yang dilakukan pada tanggal 16 Februari 2019 :

"Kegiatan diseminasi hasil diklat yang dilakukan di aula MTsN 2 Pekalongan, disambut positif oleh Kepala Madrasah. Manfaat dapat dirasakan secara langsung oleh guru - guru yang belum memiliki kesempatan mengikuti diklat Publikasi Ilmiah". 
Pernyataan tersebut juga didukung oleh wawancara dengan Pak Amin pada tanggal 9 Januari 2019, alumni diklat yang menyatakan bahwa :

"Hasil diklat akan lebih bermanfaat apabila ditularkan kepada sesama rekan Kepala maupun rekan guru - guru, sehingga pengetahuan dan wawasan tentang PKG dan PKB akan lebih luas dan merata"

Hal tersebut diatas, dikuatkan oleh hasil dari studi dokumen tentang laporan implementasi RTL dari Alumni DDWK Publikasi Ilmiah di Kankemenag Kab. Pekalongan yang dibawa langsung ke BDK Semarang oleh Bapak Sobirin selaku Kepala Madrasah MTsN 2 Pekalongan sejumlah 40 bendel laporan. Sedangkan laporan implementasi RTL dari alumni DDWK PKG PKB Kab. Tegal diserahkan langsung ke BDK Semarang oleh Ibu Fasikhah selaku Pengawas Kankemenag Kab. Tegal.

Dari hasil wawancara yang diperkuat dengan dokumen berupa laporan implementasi RTL, didapatkan bahwa alumni diklat PKG dan PKB di Kankemenag Kab. Tegal, diklat publikasi ilmiah di Kankemenag Kab. Pekalongan dan diklat pembelajaran tematik RA angkatan 2 telah melakukan transfer pembelajaran kepada sesama teman sejawat (guru) melalui kegiatan diseminasi yang dibuktikan dengan laporan hasil implementasi RTL yang dilampiri dengan RTL yang sudah dibuat ketika menjadi peserta diklat, daftar hadir kegiatan diseminasi, produk kegiatan diseminasi dan dokumentasi kegiatan diseminasi. Jumlah peserta diseminasi bervariasi dari 5 guru sampai 50 guru. Kegiatan diseminasi berupa tatap muka yang dilakukan juga bervariasi mulai dari sosialisasi kepada teman sejawat (guru) di madrasah, KKG/MGMP di tingkat kecamatan dan tingkat kabupaten/Kota.

Agar diseminasi hasil diklat dapat membantu memberikan akses pemerataan pendidikan kepada teman sejawat (guru) lainnya yang tidak secara langsung mengikuti diklat maka melalui pendekatan kepada pengurus KKG/MGMP diharapkan alumni diklat dapat meminta waktu untuk menyampaikan hasil-hasil diklat yang diperolehnya melalui kegiatan atau pertemuan yang secara rutin sudah dilakukan di KKG/MGMP. Terdapat beberapa cara untuk melakukan diseminasi hasil diklat di antaranya yaitu : mailing list, e-mail, mailbase list, newsleter, reports, websites, briefings, workshops, roadshows, conferences, one-to-one, dan media. Dari beberapa media pengimbasan di tersebut yang sudah tidak asing di kalangan guru dapat dikelompokkan menjadi 3 katagori, yaitu dalam bentuk: (a) bahan elektronik, (b) bahan nonelektronik, dan (c) tatap muka. Media pengimbasan dalam bentuk bahan elektronik dapat disampaikan melalui e- 
mail, mailing list, dan website. Sedangkan media pengimbasan bentuk bahan nonelektronik dapat disampaikan melalui buletin atau bentuk forum karya ilmiah guru lainnya. Sementara itu untuk media pengimbasan bentuk tatap muka dapat dilaksanakan melalui workshop, seminar atau konferensi yang diselenggarakan oleh KKG/MGMP (Wijaya, 2013).

Beberapa kendala yang dihadapi alumni diklat dalam melakukan transfer pembelajaran melalui kegiatan diseminasi RTL adalah motivasi diri sendiri, dukungan dan komitment atasan (Kepala Madrasah), iklim dan lingkungan di madrasah serta perencanaan waktu kegiatan diseminasi yang kurang sesuai. Hal ini sejalan dengan Wibowo (2013) yang melakukan penelitian terhadap alumni guru agama, bahwa terdapat berbagai faktor yang dapat mempengaruhi pengimplementasian hasil kediklatan guru di antaranya adalah kualitas sumber daya manusia, kondisi sosial ekonomi, fasilitas, sosiokultural, dan struktural. Sumber daya manusia yang dapat mengimplementasikan hasil diklat haruslah memiliki kualifikasi seperti motivasi tinggi, kompetensi dalam bidangnya, dan kreativitas yang tinggi. Fasilitas yang tersedia di madrasah memberikan peluang bagi guru untuk memilih secara tepat cara apa yang sesuai dengan tujuan pembelajaran dapat berlangsung menyenangkan dan menarik.
Iklim akademis sekolah yang mempengaruhi meliputi: (a) sarana pendukung; (b) fasilitas yang tersedia; (c) manajemen, program, dan regulasi madrasah; dan (d) komitmen kepala madrasah untuk melaksanakan regulasi madrasah. Hastari (2013) juga menambahkan bahwa learning transfer (transfer pembelajaran) akan berhasil jika adanya (1) dukungan dari atasan, teman sejawat dan bawahan di tempat mereka bekerja, (2) dukungan sarana prasarana, para alumni juga mengungkapkan bahwa sarana prasarana sangat dibutuhkan untuk menunjang penerapan learning transfer , (3) adanya peluang untuk menerapkan ilmu yang diperoleh dari diklat, (4) adanya motivasi dari diri sendiri untuk bertanggungjawab menerapkan ilmu hasil diklat di tempat kerjanya. Selain faktor pendukung, ada faktor-faktor penghambat, diantaranya (1) ketiadaan dukungan aktif oleh iklim organisasional untuk transfer/perpindahan dari isi program atau ketrampilan-ketrampilan ditempat kerja; (2) materi diklat dan segala penunjang diklat baik materi maupun program dari instansi penyelenggara kurang mengena untuk para peserta diklat (3) kurangnya dukungan dari lingkungan kerja di madrasah. 


\section{E. PENUTUP}

\section{Kesimpulan}

Transfer pembelajaran telah diimplementasikan oleh alumni diklat kepada teman sejawat (sesama guru) melalui kegiatan diseminasi RTL dengan jenis materi sesuai jenis diklat dan waktu pelaksanaan yang sudah ditentukan saat menyusun RTL, diakhiri dengan penyusunan laporan hasil implementasi RTL dengan menyertakan lampiran seperti daftar hadir, dokumentasi dan produk kegiatan yang kemudian dikirimkan ke Balai Diklat Keagamaan sebagai instansi penyelenggara diklat. Dalam kegiatan diseminasi, alumni melakukan sosialisasi kepada sesama rekan guru, baik sesama guru Mapel maupun sesama guru di lingkungan madrasah (MGMP tingkat madrasah), ada juga yang melakukan kegiatan diseminasi dalam forum KKG/MGMP tingkat kecamatan sampai tingkat Kab/Kota dengan jumlah peserta 5 sampai 50 guru.

Beberapa kendala yang dihadapi alumni diklat dalam melakukan transfer pembelajaran melalui kegiatan diseminasi antara lain : adalah motivasi diri sendiri, dukungan dan komitment atasan (Kepala Madrasah), iklim dan lingkungan di madrasah serta perencanaan waktu kegiatan diseminasi yang kurang sesuai.

\section{Saran}

Balai Diklat Keagamaan sebagai penyelenggara diklat telah mewajibkan setiap peserta diklat menyusun RTL, melakukan diseminasi RTL, menyusun laporan implementasi RTL dan mengirimkan laporannya ke BDK sebagai salah satu wujud transfer pembelajaran dari alumni diklat kepada sesama teman sejawat (guru). Saran yang dapat disampaikan agar program pemberdayaan alumni mendapat perhatian karena menjadi salah satu bahan untuk melakukan evaluasi, khususnya evaluasi pasca diklat.

\section{DAFTAR PUSTAKA}

Asroi. (2013). Analisis Dampak Kegiatan Diklat Terhadap Peningkatan Kualitas Proses Kerja (Study Kualitatif Pada Alumni Diklat di Lingkungan Balai Diklat Keagamaan Jakarta. Artikel, 1-11.

Hanum, F. (2018). Evaluasi Penyelenggaraan Diklat Di Kementerian Agama. Edukasi (Jurnal Penelitian Pendidikan Agama dan Keagamaan, 16(2), 2018, 191-203.

Haryanto. (2011). Analisis Pengukuran Efektivitas Diklat. Jurnal IImu Administrasi Edisi 01/Tahun XVII/2011, 38 - 43.

Hastari, T. (2013). Studi Deskriptif Tentang Learning Transfer Bagi Alumni Peserta Pendidikan dan Pelatihan Pelayanan Publik oleh Badan Pendidikan dan Pelatihan Jawa Timur di Badan Koordinasi Wilayah Malang. Jurnal Kebijakan dan Manajemen Publik Volume 1 No.1, 1-7.

Julifan, J. A. (2015). Efektivitas Manajemen Pendidikan dan Pelatihan Berbasis Kompetensi . Jurnal Administrasi Pendidikan, Vol.XXII No.2 Oktober 2015 . 
Noe, R. (2010). Employee Training and Development 5th ed. Singapore: Mc Graw-Hill International Edition.

Pertissa, 0. d. (2015). Pengaruh Stres Kerja Dan Motivation To Transfer Terhadap Transfer of Learning Pegawai Pengadilan Agama Padang. Analisa, 127.

Soekamto, T. d. (1997). Teori Belajar dan Model - Model Pembelajaran. Jakarta: Dikti, Depdiknas.

Sugiyono. (2013). Metode Penelitian Manajemen. Bandung : Alfabeta

Sumarni, E. d. (2013). Pengaruh Iklim Transfer Terhadap Motivasi Transfer Dan Transfer Pelatihan Bagi Para Pegawai Administratif Universitas Jambi. Jurnal Dinamika Manajemen Vol. 1 No. 2 April - Juni 2013 , 81-93.

Tasee, A. a. (2005, January 1). The Role of the SUpervisor. Retrieved January 1, 2015, from The Role of the Supervisor: http://www.wln.ualberta.ca/paper/ pdf/41.pdf

Wibowo, A. (2013). Kinerja Guru Agama Madrasah Aliyah Pasca Diklat Fungsional Di Propinsi Nusa Tenggara Barat. Jurnal "Analisa" Volume 20 Nomor 02 Desember 2013, 245-256.

Wijaya, A. (2013). Upaya Pemerataan Akses Pendidikan (Diklat) Melalui Berbagi Bentuk Kegiatan Diseminasi Hasil Diklat. Yogyakarta: Pusat Pengembangan dan Pemberdayaan Pendidikan dan Tenaga Kependidikan (P4TK) Matematika. 